\title{
Sanitary landfill leachate as a source of nutrients on the initial growth of sunflower plants
}

\author{
Francisco H. Nunes Júnior ${ }^{1}$, Franklin A. Gondim², Magnum de S. Pereira ${ }^{3}$, \\ Brennda B. Braga ${ }^{2}$, Roberto A. Pontes Filho ${ }^{4} \&$ Francisca E. L. Barbosa ${ }^{5}$ \\ ${ }^{1}$ Instituto Federal de Educação, Ciência e Tecnologia do Ceará/Laboratório de Bioquímica e Fisiologia Vegetal. Jaguaribe, CE. E-mail: holandajrb@gmail.com \\ ${ }^{2}$ Instituto Federal de Educação, Ciência e Tecnologia do Ceará/Laboratório de Bioquímica e Fisiologia Vegetal. Maracanaú, CE. E-mail: aragaofg@yahoo.com.br \\ (Corresponding author); brennda.bbb@hotmail.com \\ ${ }^{3}$ Universidade Federal do Ceará/Centro de Ciências/Departamento de Química Orgânica e Inorgânica. Fortaleza, CE. E-mail: magnum.ufc@gmail.com \\ ${ }^{4}$ Instituto Federal de Educação, Ciência e Tecnologia do Ceará/Laboratório Terra. Maracanaú, CE. E-mail: roberto.consultorambiental@gmail.com \\ ${ }^{5}$ Instituto Federal de Educação, Ciência e Tecnologia do Ceará/Eixo de Tecnologia em Alimentos. Ubajara, CE. E-mail: barbosaedineide@yahoo.com.br
}

\section{Key words:}

urban waste

Helianthus annus L.

growth analysis

\begin{abstract}
A B S T R A C T
The aim of this study was to evaluate the initial growth of sunflower seedlings under different concentrations of sanitary landfill leachate, considering the feasibility of its use as source of nutrients for agricultural production. Biometric and vigor variables were analyzed through the measurements of collar diameter, shoot height, number of leaves and shoot and root fresh and dry matters, from January to February 2015. The experimental design was completely randomized in a $5 \mathrm{x} 4$ factorial scheme: five leachate concentrations $(0,40$, 60,80 and $\left.100 \mathrm{~kg} \mathrm{~N} \mathrm{ha}^{-1}\right) \mathrm{x}$ four harvest periods (14,21, 25 and 29 days after sowing), with five replicates each containing two plants. The data were subjected to analysis of variance and polynomial regression, and the results of the last harvest (29 DAS) were compared by Tukey test $(\mathrm{p} \leq 0.05)$. The use of sanitary landfill leachate increased all analyzed variables in sunflower plants when compared to the control plants (without leachate), especially in the treatment of $100 \mathrm{~kg} \mathrm{~N} \mathrm{ha}^{-1}$. There was no inhibitory effect of the leachate on the initial growth of sunflower seedlings under adopted experimental conditions.
\end{abstract}

\section{Palavras-chave: resíduo urbano Helianthus annus L.} análise de crescimento

\section{Percolado de aterro sanitário como fonte de nutrientes no crescimento inicial de plantas de girassol}

\section{R E S U M O}

Buscou-se, neste trabalho, analisar o crescimento inicial de plântulas de girassol submetidas a diferentes concentrações de percolado de aterro sanitário verificando a viabilidade da sua utilização como fonte de nutrientes para produção agrícola. Foram avaliadas variáveis biométricas e de vigor através das medidas de diâmetro do coleto, altura da parte aérea, número de folhas e produção de matérias frescas e secas das raízes e partes aéreas, no período de Janeiro a Fevereiro de 2015. O delineamento experimental foi o inteiramente casualizado disposto em arranjo fatorial com cinco concentrações de percolado $(0,40,60,80$ e $100 \mathrm{~kg}$ $\left.\mathrm{N} \mathrm{ha}^{-1}\right)$ x quatro períodos de coleta $(14,21,25$ e 29 dias após semeadura), contendo cinco repetições com duas plantas por repetição. Os dados obtidos foram submetidos à análise de variância, regressão polinomial e as médias do último período de coleta comparadas pelo teste de Tukey $(\mathrm{p} \leq 0,05)$. Verificou-se que a utilização de percolado de aterro sanitário promoveu incrementos em todas as variáveis analisadas em relação ao controle (ausência de percolado), especialmente no tratamento de $100 \mathrm{~kg} \mathrm{~N} \mathrm{ha}^{-1}$. Não houve efeito inibitório do percolado no crescimento inicial das plântulas de girassol nas condições experimentais empregadas.

Ref. 138-2015 - Received 16 Sep, 2015 • Accepted 14 Jun, 2016 • Published 12 Jul, 2016 


\section{INTRODUCTION}

The correct disposal of solid urban waste (SUW) is one of the main environmental problems in the world (Yang et al., 2013). Sanitary landfills are an accepted alternative for the destination of SUW from urban centers worldwide; however, it generates by-products that may cause serious damages to the environment, such as the leachate (or percolate), which originates from the interaction between moisture and the residues compacted in the landfill cells (Kirmizaks et al., 2014).

Organic matter is one of the main components of the leachate, complemented by a large load of heavy metals, which tends to decrease their toxic effects and bioavailability over time (Xi et al., 2012).

The use of SUW in plant cultivation has been analyzed as a possible alternative for the solution of the final destination of the effluent. Avramidou et al. (2013) and Tzortzakis et al. (2012) utilized sanitary landfill leachate after composting and applied it through fertigation in plants.

Additionally, the high costs of chemical fertilizers stimulate the search for less expensive alternatives, such as the use of organic fertilization from residues, optimizing the utilization of SUW (Karak et al., 2014).

Sunflower (Helianthus annus L.) is among the species with highest potential in the supply of raw material for biofuel production in Brazil (Freitas et al., 2012). This fact is mainly due to the high content of oil in its seeds and its wide adaptation to different climates and soils (Prado \& Leal, 2006).

Given the above, this study aimed to analyze the initial growth of sunflower (Helianthus annuus L.) seedlings subjected to different concentrations of sanitary landfill leachate under greenhouse conditions, observing the viability of its use as a source of nutrients for agricultural production.

\section{Material AND Methods}

The leachate used in the experiment was collected in January 2015, at the West Metropolitan Sanitary Landfill of Caucaia (ASMOC) in the third stabilization pond (facultativeaerobic) close to the spillway located in Caucaia, CE, Brazil. The collection of the effluent followed the norms of stocking, maintenance and transport according to the analyzed physicochemical and microbiological parameters (Tables 1 and 2).

According to the results of the physicochemical analysis, the leachate showed in its composition some of the main macro- $(\mathrm{N}, \mathrm{P}, \mathrm{K}, \mathrm{Ca}$ and $\mathrm{Mg})$ and micronutrients $(\mathrm{Cl}, \mathrm{Cu}$, $\mathrm{Fe}, \mathrm{Mn}$ and $\mathrm{Zn}$ ) required in plant nutrition. Additionally,
Table 2. Microbiological analyses

\begin{tabular}{ccc}
\hline Attributes & Value & Unit \\
Fecal coliforms & $<2$ & MPN $100 \mathrm{~mL}^{-1}$ \\
Total coliforms & Absence & MPN $100 \mathrm{~mL}^{-1}$ \\
\hline MPN - Most probable number of coliforms
\end{tabular}

environmental parameters (such as heavy metals), electrical conductivity and $\mathrm{pH}$ are within the acceptable levels established by CETESB (2014).

The experiment was conducted from January to February 2015 in a greenhouse located in the city of Maracanaú, CE, Brazil (0352' 36" S; 38 37' 32” W; $40 \mathrm{~m}$ ). The mean values of temperature and relative air humidity in the greenhouse were $26.6^{\circ} \mathrm{C}$ and $65 \%$, respectively.

The seeds of sunflower (Helianthus annuus L.), cv. BRS 323, were provided by Embrapa Products and Markets - Office of Dourados, MS, Brazil. After selection and disinfection with $0.7 \%$ sodium hypochlorite solution, the seeds were sown in $5-\mathrm{L}$ plastic pots filled with sand of fine granulometry (NBR 6502).

Four applications of sanitary landfill leachate were performed in the pots: at sowing, and at 07,14 and 21 days after sowing (DAS). The volumes were defined based on the total nitrogen $(\mathrm{N})$ content of the leachate sample (364 $\mathrm{mg} \mathrm{L}^{-1}$ ) and proportionally applied in the pots in order to correspond to one hectare in field conditions. The applied leachate volumes resulted in the following $\mathrm{N}$ doses: 0, 40, 60, 80 and $100 \mathrm{~kg} \mathrm{ha}^{-1}$. During the experiment, daily waterings were performed, maintaining substrate moisture close to $70 \%$ of field capacity.

The experimental design was completely randomized, arranged in a $5 \times 4$ factorial scheme, which corresponded to five leachate concentrations $\left(0,40,60,80\right.$ or $\left.100 \mathrm{~kg} \mathrm{~N} \mathrm{ha}^{-1}\right)$ and four harvest periods $(14,21,25$ or 29 DAS), with five replicates containing two plants each, totaling 100 experimental units. The data were subjected to analysis of variance (ANOVA) and polynomial regression using the statistical program Sisvar 5.4 (Ferreira, 2010).

The harvests of plant material were performed at 14, 21, 25 and 29 DAS. Plants were separated into roots, stem and leaves for the determination of root fresh matter (RFM) and shoot fresh matter (SFM). Then, the material was dried in a forced-air oven at $60^{\circ} \mathrm{C}$, for the determination of root dry matter (RDM) and shoot dry matter (SDM).

In each harvest, collar diameter (CD) was determined using a digital caliper $(0.01 \mathrm{~mm})$ at the insertion of the epicotyl-hypocotyl axis; shoot height $(\mathrm{SH})$, measured with a ruler graduated in centimeters, from the soil surface until the last node; and number of leaves (NL), obtained through manual count.

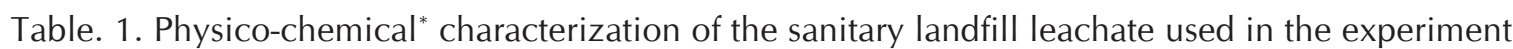

\begin{tabular}{|c|c|c|c|c|c|c|c|c|c|c|c|c|}
\hline \multicolumn{13}{|c|}{ Physico-chemical parameters } \\
\hline BOD & COD & TS & $\mathrm{N}-\mathrm{t}$ & P-t & $\mathrm{Fe}^{+2}$ & $\mathrm{Zn}$ & Mn & $\mathrm{Cu}$ & Cd & $\mathrm{Cr}$ & $\mathrm{Pb}$ & $\mathrm{Ni}$ \\
\hline \multicolumn{8}{|c|}{$\mathrm{mg} \mathrm{L}^{-1}$} & \multicolumn{5}{|c|}{$\mu \mathrm{g} \mathrm{L}^{-1}$} \\
\hline 187.7 & 1545 & 61 & 364 & 4.9 & 3.2 & 4.3 & 2.2 & 90.4 & 1.0 & 21.8 & $<10$ & 103 \\
\hline SAR & $\mathbf{K}^{+}$ & $\mathrm{Na}^{+}$ & $\mathrm{Ca}^{2+}$ & $\mathrm{Mg}^{2+}$ & $\mathrm{Cl}^{-}$ & $\mathrm{CO}_{3}{ }^{-2}$ & $\mathrm{HCO}_{3}^{-}$ & & \multirow{2}{*}{ pH } & EC & \multirow{2}{*}{\multicolumn{2}{|c|}{$\begin{array}{c}\text { Color } \\
\text { HII }\end{array}$}} \\
\hline \multicolumn{8}{|c|}{$\mathrm{mmol}_{\mathrm{c}} \mathrm{L}^{-1}$} & & & $\mathrm{dS} \mathrm{m}^{-1}$ & & \\
\hline 6.0 & 29.5 & 36.9 & 24.2 & 49.2 & 72.4 & 2.1 & 54.8 & & 8.5 & 12.2 & 2000 & \\
\hline
\end{tabular}

* BOD - Biological oxygen demand; COD - Chemical oxygen demand; TS - Total solids; SAR - Sodium adsorption rate; EC - Electrical conductivity; HU - Hazen unit 


\section{Results AND Discussion}

According to the ANOVA (Table 3), the use of sanitary landfill leachate as a source of total $\mathrm{N}$ in sunflower fertilization significantly affected $(\mathrm{P} \leq 0.01)$ all analyzed variables, with interaction between total $\mathrm{N}$ concentrations (treatments) and the time (days after sowing).

Figure 1 shows the response curves of sunflower seedlings for the variables collar diameter (Figure 1A), shoot height (Figure 1B) and number of leaves (Figure 1C) over time. In general, the treatments of 60 and $100 \mathrm{~kg} \mathrm{~N} \mathrm{ha}^{-1}$ promoted the highest increments in the analyzed variables, which fitted best to a cubic regression model, with adjustment coefficient of $\mathrm{R}^{2}$ $=1$ in the treatment of $100 \mathrm{~kg} \mathrm{~N} \mathrm{ha}^{-1}$ for collar diameter and number of leaves and $60 \mathrm{~kg} \mathrm{~N} \mathrm{ha}^{-1}$ for shoot height.

Sigmoid growths represent three phenological stages that are characteristic of a living organism and, in the case of plants, there were slower growths in the beginning, due to the structuration of the photosynthetic apparatus. Then, there is an increase in the growth rate with positive balance in organic matter accumulation until a final tendency to stabilization caused by the overlapping of older leaves by the recently formed ones (Moraes \& Palhano, 2002).

$\mathrm{N}$ is one of the main macronutrients associated with plant growth; low concentrations directly affect the number of leaves, leaf area, collar diameter and plant height (Silva et al., 2010). In general, the analyses of collar diameter (Figure 1A), shoot height (Figure 1B) and number of leaves (Figure 1C) demonstrated that the application of leachate to the growing environment promoted increase in the values of these variables, in comparison to the control treatment.

For the same variables, there was an increment in the treatments of $40,60,80$ and $100 \mathrm{~kg} \mathrm{~N} \mathrm{ha}^{-1}$ in relation to the control, for all harvest periods; however, the highest differences occurred at 29 DAS (Figure 1) in the treatments of $60 \mathrm{~kg} \mathrm{~N}$ $\mathrm{ha}^{-1}$ for shoot height $(78.5 \%), 100 \mathrm{~kg} \mathrm{~N} \mathrm{ha}^{-1}$ for collar diameter $(50.8 \%)$ and 60 and $100 \mathrm{~kg} \mathrm{~N} \mathrm{ha}^{-1}$ for the number of leaves (29\%).

Considering the above mentioned results, the increment in number of leaves can be highlighted, given its importance in the photosynthetic process, especially when associated with the increase in leaf area (Karadogan \& Akgün, 2009).

Additionally, considering a ratio between plant growth in height and number of leaves, there were increments of $8 \mathrm{~cm}$ in height for every 2.5 leaves developed by the seedlings, in the treatment of $60 \mathrm{~kg} \mathrm{~N} \mathrm{ha}^{-1}$ (corresponding to about $160 \mathrm{mg}$ $\mathrm{L}^{-1}$ of $\mathrm{N}$ ). This result is similar to that reported by Fagundes
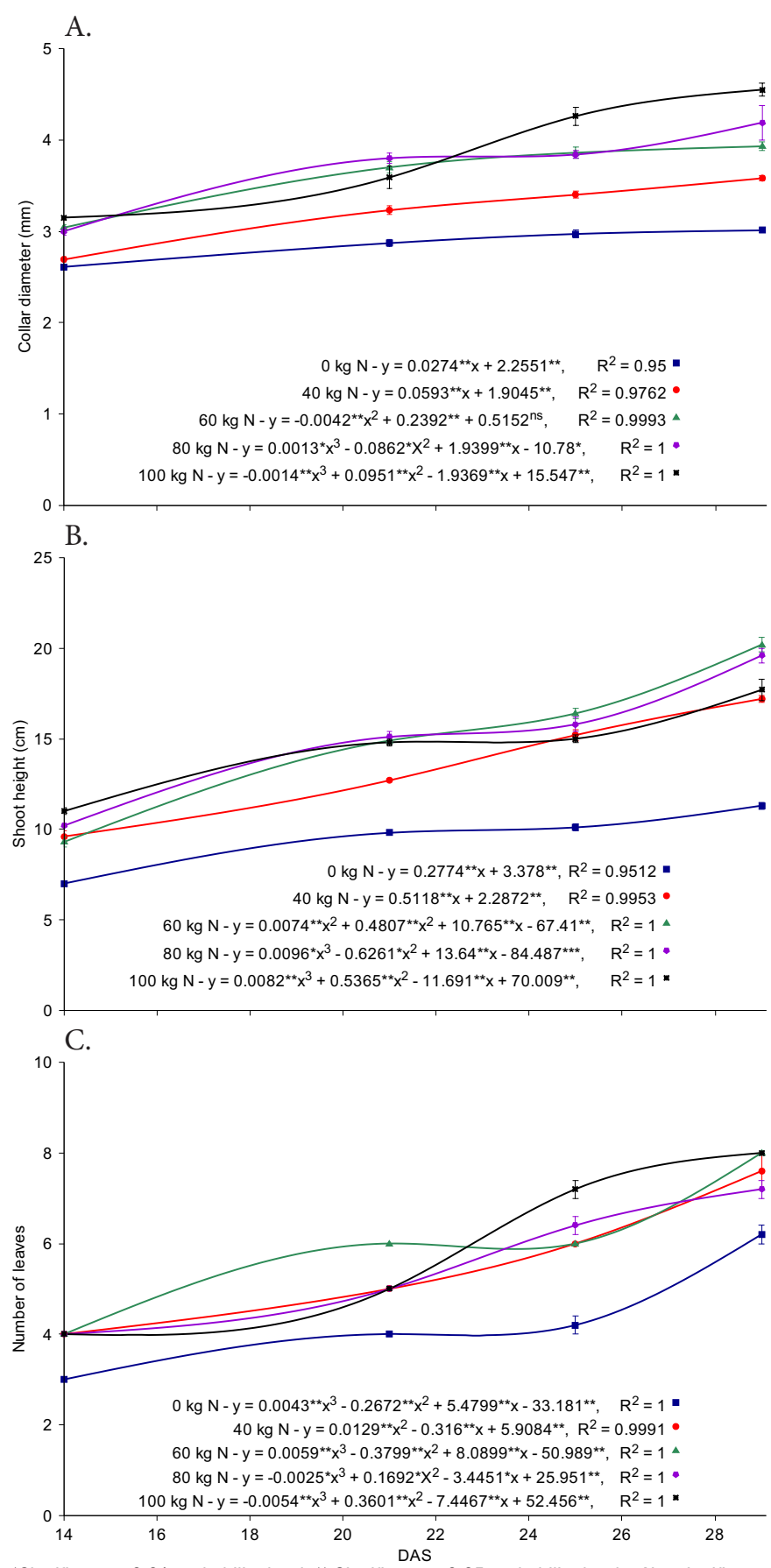

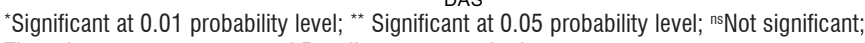
The values represent means of 5 replicates \pm standard errors

Figure 1. Collar diameter (A), shoot height $(B)$ and number of leaves $(\mathrm{C})$ of sunflower seedlings subjected to different concentrations of sanitary landfill leachate as a source of total $\mathrm{N}$ in different harvest periods, in days after sowing (DAS)

Table 3. Summary of the analysis of variance for number of leaves (NL), collar diameter (CD), shoot height (SH), root fresh matter (RFM), shoot fresh matter (SFM), root dry matter (RDM) and shoot dry matter (SDM) of sunflower seedlings subjected to different concentrations of sanitary landfill leachate as a source of total $\mathrm{N}$ over time

\begin{tabular}{|c|c|c|c|c|c|c|c|c|}
\hline \multirow{2}{*}{ Source of variation } & \multirow{2}{*}{ DF } & \multicolumn{7}{|c|}{ Mean square } \\
\hline & & NL & CD & SH & RFM & SFM & RDM & SDM \\
\hline Treatment & 4 & $9.56^{\star *}$ & $3.4^{\star \star}$ & $112.4^{\star *}$ & $1.0^{* *}$ & $13.9^{* \star}$ & $0.01^{\star *}$ & $0.22^{\star *}$ \\
\hline Time & 3 & $57.96^{* *}$ & $4.25^{* *}$ & $260.4^{* *}$ & $3.76^{* *}$ & $23.8^{* *}$ & $0.06^{* *}$ & $0.71^{* *}$ \\
\hline Treatment $x$ time & 12 & $0.92^{\star \star}$ & $0.18^{\star \star}$ & $6.1^{\star \star}$ & $0.25^{* *}$ & $1.6^{* *}$ & $0.0^{* \star}$ & $0.05^{\star *}$ \\
\hline Error & 80 & 0.09 & 0.02 & 0.39 & 0.0 & 0.0 & 0.0 & 0.0 \\
\hline Total corrected & 99 & - & - & - & - & - & - & - \\
\hline CV (\%) & - & 5.5 & 4.3 & 4.6 & 8.1 & 3.7 & 10.1 & 7.1 \\
\hline
\end{tabular}

${ }^{* *}$ Significant at 0.01 by $F$ test, DF - Degrees of freedom; CV - Coefficient of variation 
et al. (2007) in sunflower plants fertilized with commercial $\mathrm{N}$ $\left(150 \mathrm{mg} \mathrm{L}^{-1} \mathrm{~N}\right)$. These authors observed increments of $8 \mathrm{~cm}$ in height for every 3 leaves developed.

Regarding dry matter variables, a quadratic equation $\left(\mathrm{R}^{2}\right.$ $=0.9992$ ) described the response curve of the treatment with highest increments in RDM (Figure 2A), while a cubic equation described such response curve for SDM (Figure 2B), as observed for collar diameter, shoot height and number of leaves.

For the variables RDM and SDM (Figure 2A and 2B), the treatment of $100 \mathrm{~kg} \mathrm{~N} \mathrm{ha}^{-1}$ obtained the highest accumulations at the end of the harvest period, in relation to the control, with differences of 228 and $300 \%$, respectively.

The results obtained in the present study differ from those described by Silva Filho et al. (2005); these authors analyzed the use of landfill leachate in the cultivation of four plant species (Arachis repen, Paspalum notatum, Penniscetum setaceum and Zoysia japônica) with potential for recovering degraded areas, and observed that increasing concentrations of leachate diluted in water led to substantial yield reductions.

Growth inhibition in plants subjected to fertilization with organic waste is common and normally associated with the toxicity of the compounds. Many residues show high concentration of heavy metals, which ultimately affect the growth and development of crops that are not tolerant to such condition (Ataíde et al., 2011).

In Brazil, there is not yet a specific legislation for the use of residues in agriculture (Rossol et al., 2012). Thus, for the monitoring of the load of nutrients and contents of heavy metals in residues applied in agriculture, some authors (Mendes et al., 2010; Santos et al., 2010) have used as a reference the report of the Environmental Sanitation Technology Company of the São Paulo state (CETESB), which establishes guiding values for soils and groundwaters.

A.
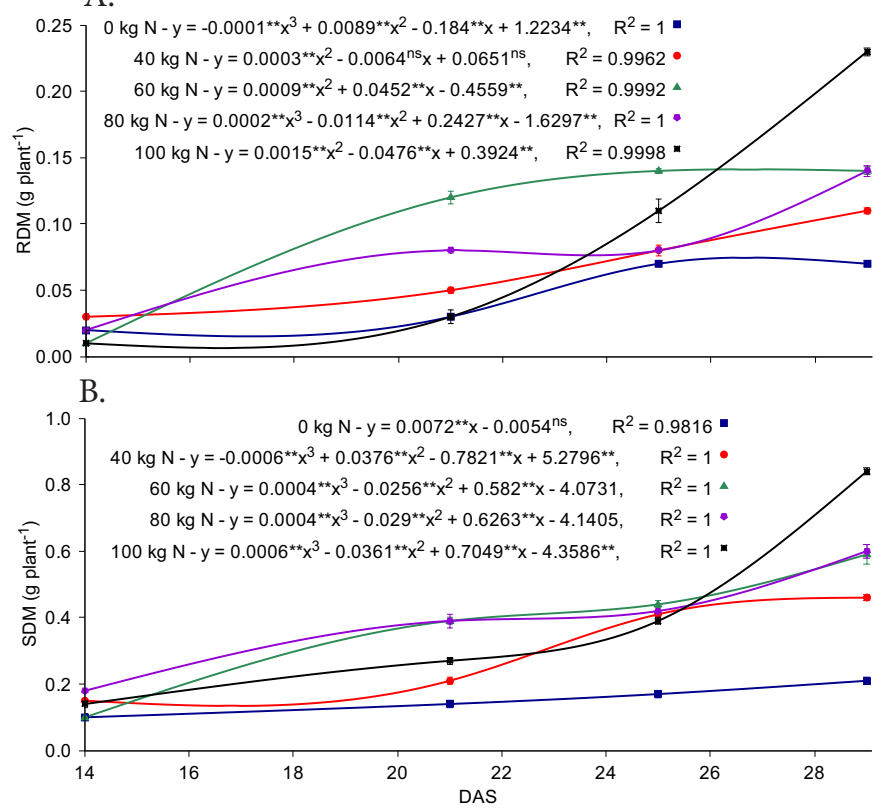

*Significant at 0.01 probability level; "*Significant at 0.05 probability level; nsNot significant; The values represent means of 5 replicates \pm standard errors

Figure 2 . Root dry matter (A) and shoot dry matter (B) of sunflower seedlings subjected to different concentrations of sanitary landfill leachate as a source of total $\mathrm{N}$ in different harvest periods, in days after sowing (DAS)
In the present study, there were no inhibitions in sunflower growth due to the use of the leachate; however, it may be related to two factors: 1) the selection of sunflower (Helianthus annus L.), a plant with recognized tolerance to many metals, considered as phytoextractor, which allows its use even in the phytoremediation of contaminated soils (Boonyapookana et al., 2005); and 2) based on the initial concentrations of metals in the leachate (Table 1), it is believed that, at the end of the experimental period, the concentrations in the substrate did not exceed the guiding limits established by CETESB (2014).

The minimal and maximal fertilizations recommended for sunflower vary from 40 to $80 \mathrm{~kg} \mathrm{~N} \mathrm{ha}^{-1}$ (Lobo et al., 2011). Thus, the highest values observed in the treatment of $100 \mathrm{~kg}$ $\mathrm{N} \mathrm{ha}^{-1}$, in most analyzed variables, show that it is possible to apply higher concentrations of the leachate (under the physicochemical conditions and in the plant development stages used in the present study); however, new studies and especially field analyses are necessary.

Additionally, the increasing and different increments observed in the treatments with leachate concentrations (40, 60,80 and $100 \mathrm{~kg} \mathrm{~N} \mathrm{ha}^{-1}$ ) during the experimental period suggest the possibility of utilization of the leachate (as source of total $\mathrm{N}$ and other macronutrients) in the cultivation of sunflower plants, which constitutes a possible alternative for the destination of the residue.

\section{Conclusions}

1. The varied doses of sanitary landfill leachate (amounts used, physicochemical conditions and period of analysis) utilized in the substrates of cultivation of sunflower seedlings promoted increments in all analyzed variables, in relation to the control (absence of leachate in the substrate).

2. Under the conditions used in this experiment, the values of collar diameter, number of leaves and dry matter accumulations in the treatment of $100 \mathrm{~kg} \mathrm{~N} \mathrm{ha}^{-1}$ demonstrated that it is possible to use even higher leachate doses for agricultural production.

\section{Literature Cited}

Ataíde, L. M. S.; Lopes, S. R.; Rosa, C. S.; Simões, D. A.; Tavares, K. G. Avaliação da fitotoxicidade de compostos orgânicos a partir de ensaios biológicos envolvendo sementes de tomate. Scientia Plena, v.7, p.1-12, 2011.

Avramidou, P.; Evangelou, A.; Komolis, D. Use of municipal solid waste compost as a growth media for an energy plant (rapessed). Journal of Evironmental Management, v.121, p.152-159, 2013. http://dx.doi.org/10.1016/j.jenvman.2013.02.046

Boonyapookana, B.; Parkplan, P.; Techapinyawat, S.; Delaune, R. D.; Jugsujinda, A. Phytoaccumulation of lead by sunflower (Helianthus annuus), tobacco (Nicotiana tabacum), and vetiver (Vetiveria zizanioides). Journal of Environmental Science and Health, Part A: Toxic/Hazardous Substances and Environmental Engineering, v.40, p.117-137, 2005. http://dx.doi.org/10.1081/ ESE-200033621

CETESB - Companhia de Tecnologia de Saneamento Ambiental. Relatório de estabelecimento de valores orientadores para solos e águas subterrâneas no estado de São Paulo. Diário Oficial Poder Executivo - Seção I, SP, v.124, n.36, p.53, 2014. 
Fagundes, J. D.; Santiago, G.; Mello, A. M. de; Bellé, R. A.; Streck, N. A. Crescimento, desenvolvimento e retardamento da senescência foliar em girassol de vaso (Helianthus annus L.): Fontes e doses de nitrogênio. Ciência Rural, v.37, p.987-993, 2007. http://dx.doi. org/10.1590/S0103-84782007000400011

Ferreira, D. F. Sisvar - Sistema de análise de variância. Versão 5.4. Lavras: UFLA, 2010.

Freitas, C. A. S. de; Silva, A. R. A. da; Bezerra, F. M. L.; Andrade, R. R. de; Mota, F. S. B.; Aquino, B. F. de. Crescimento da cultura do girassol irrigado com diferentes tipos de água e adubação nitrogenada. Revista Brasileira de Engenharia Agrícola e Ambiental, v.16, p.10311039, 2012. http://dx.doi.org/10.1590/S1415-43662012001000001

Karadogan, T.; Akgün, Í. Effect of leaf removal on sunflower yield and yield components and some quality characters. Helia, v.32, p.123-134, 2009. http://dx.doi.org/10.2298/HEL0950123K

Karak, T.; Paul, R. K.; Sonar, I.; Sanyl, S.; Ahmed, K. Z.; Boruah, R. K.; Das, D. K.; Dutta, A. K. Chromium in soil and tea (Camellia sinensis L.) infusion: Does soil amendment with municipal solid waste compost make sense? Food Research International, v.64, p.114-124, 2014. http://dx.doi.org/10.1016/j.foodres.2014.06.006

Kirmizaks, P.; Tsamoutsoglou, C.; Kayan, B.; Kalderis, D. Subcritical water treatment of landfill leachate: Application of response surface methodology. Journal of Environmental Management, v.146, p.915, 2014. http://dx.doi.org/10.1016/j.jenvman.2014.04.037

Lobo, T. F.; Grassi Filho, H.; Britto, I. C. A. Efeito do nitrogênio na nutrição do girassol. Bioscience Journal, v.27, p.380-391, 2011.

Mendes, A. M. S.; Duda, G. P.; Nascimento, C. W. A. do; Lima, J. A. G.; Medeiros, A. D. L. Acúmulo de metais pesados e alterações químicas em cambiossolo cultivado com meloeiro. Revista Brasileira de Engenharia Agrícola e Ambiental, v.18, p.791-796, 2010. http://dx.doi.org/10.1590/S1415-43662010000800001

Moraes, A.; Palhano, A. L. Fisiologia de produção de plantas forrageiras. In: Wachowicz, C. M.; Carvalho, R. I. N. Fisiologia vegetal: Produção e pós-colheita. Curitiba: Champagnat, 2002. p.249-271.
Prado, R. de M.; Leal, R. M. Desordens nutricionais por deficiência em girassol var. Catissol - 01. Pesquisa Agropecuária Tropical, v.36, p.187-193, 2006.

Rossol, C. D.; Scalon Filho, H.; Berté, L. N.; Jandrey, P. E.; Schwantes, D.; Gonçalves Júnior, A. C. Caracterização, classificação e destinação de resíduos da agricultura. Scientia Agraria Paranaensis, v.11, p.33-43, 2012. http://dx.doi.org/10.18188/19831471/sap.v11n4p33-43

Santos, C. H.; Grassi Filho, H.; Santos, J. C.; Penteado, B. B. Fertilidade do solo e nutrição de tangerinas Ponkan manejadas com resíduos sólidos e adubação química. Revista Brasileira de Engenharia Agrícola e Ambiental, v.15, p.75-83, 2010. http:// dx.doi.org/10.1590/S1415-43662011000100011

Silva, P. C. C.; Couto, J. L. do; Santos, A. R. dos. Efeitos dos íons amônio e nitrato no desenvolvimento do girassol em solução nutritiva. Revista FZVA, v.17 p.104-114, 2010.

Silva Filho, N. L. da S.; Freitas, N. P.; Teixeira, N. T.; Terra, R. A. da F.; Melo, E. C. N.; Tognocchi, S. Chorume na adubação de plantas com potencial de utilização para estabilização em aterros sanitários. Ecossistema, v.30, p.25-28, 2005.

Tzortzakis, N.; Gouma, S.; Dagianta, E.; Saridakis, C.; Papamichalaki, M.; Goumas, D.; Manios, T. Use of fertigation and municipal solid waste compost for greenhouse pepper cultivation. The Scientific World Journal, v.2012, p.1-8, 2012. http://dx.doi. org/10.1100/2012/973193

Xi, B.; He, X.; Wei, Z.; Jiang, Y.; Li, D.; Pan, H.; Liu, H. The composition and mercury complexation characteristics of dissolved organic matter in landfill leachates with different ages. Ecotoxicology and Environmental Safety, v.86, p.227-232, 2012. http://dx.doi. org/10.1016/j.ecoenv.2012.09.024

Yang, N.; Damgaard, A.; Lu, F.; Shao, L.; Brogaard, L. K.; He, P. Environmental impact assessment on the construction and operation of municipal solid waste sanitary landfills in developing countries: China case study. Waste Management, v.34, p.929-937, 2013. http://dx.doi.org/10.1016/j.wasman.2014.02.017 